\title{
ОЦЕНКА СТЕПЕНИ СФОРМИРОВАННОСТИ СИСТЕМНЫХ ОСНОВ ИНСТИТУЦИОНАЛЬНОЙ СРЕДЫ ГОСУДАРСТВЕННО-ЧАСТНОГО ПАРТНЕРСТВА В СОВРЕМЕННОЙ РОССИИ
}

\begin{abstract}
Локшин Никита Вячеславович
аспирант

ФГБОУ ВО «Российская Академия Народного Хозяйства и Государственной Службы при Президенте Российской Федерации»
\end{abstract}

Аннотация: Проведена оценка степени сформированности системных основ институциональной среды государственно-частного партнерства в современной России. Показана значимость институтов развития в этой среде. Проанализировано, как ограничения и барьеры сужают диапазон возможностей для использования различных форм государственно-частного партнерства.

Ключевые слова: государственно-частное партнерство, институты развития, концессии, институциональные условия, национальные центр ГЧП, контракт жизненного цикла.

\section{ESTIMATING DEGREE OF THE SYSTEM FOUNDATIONS OF THE INSTITUTIONAL ENVIRONMENT OF PUBLIC-PRIVATE PARTNERSHIP IN MODERN RUSSIA FORMEDNESS}

\section{Lokshin Nikita Vyacheslavovich}

\begin{abstract}
An assessment degree of formation of the systemic foundations of the institutional environment of public-private partnership in modern Russia was made. The importance of development institutions in this environment was shown. It is analyzed how restrictions and barriers narrow the range of opportunities for using various forms of public-private partnership.
\end{abstract}

Key words: public-private partnership, development institutions, concessions, institutional conditions, national PPP center, life cycle contract.

Формирование системы государственно-частного партнерства в России уходит корнями в 80-е года XX века, когда еще в СССР в 1989 г. появился закон «О кооперации», который привел к появлению первых организационных 


\section{ВСЕРОССИЙСКИЕ НАУЧНЫЕ ЧТЕНИЯ

форм выстраивания отношений государственного и частного секторов с пока еще незначительными элементами партнерства в 1990-1991 годах. Далее в условиях полного отсутствия институциональной среды или при наличии ее элементов, но их фактическом бездействии, взаимодействие государство и бизнеса в основном проявлялось в приватизации собственности, а также в формировании так называемых финансово-промышленных групп, которые стали по выражению Е.Т. Гайдара для промышленности (прежде всего, сырьевой направленности) «патронажем от государства и частного сектора в лице коммерческих банков» $[1$, с. 476].

Первые же годы XXI века для России ознаменовались появлением различных институтов развития, которые позволили государству инициировать внедрение новых форм взаимодействия партнеров со стороны государства и частного сектора: появились концессии, совместные предприятия лизинговые контракты и т.п.

Однако непосредственно государственно-частное-партнерство получило официальный статус в 2004 году, в течение которого произошло 3 ключевых события, давшие импульс для его развития:

- в Постановлении Правительства от 28 июля 2004 года «Основные направления деятельности Правительства Российской Федерации до 2008 года», в разделе, посвященном приоритетным направлениям макроэкономической политики, встречается первое упоминание термина «государственно-частное партнерство» в развернутом виде;

- в Государственной Думе был подписан закон «О концессиях», ожидавший своей очереди 12 лет;

- Правительством РФ было принято решение о формировании государственного инвестиционного фонда, размер которого в 2004 году составил 70 млрд. руб., предназначенного именно для государственного финансирования проектов государственно-частного партнёрства.

Принято считать, что 2004 год стал знаковым для развития рынка проектов, и учет всех данных, описывающих его динамику, масштабы и тенденции в России, осуществляется чаще всего именно с 2004 г. (например, по данным Единой информационной системы государственно-частного партнерства (www.pppi.ru)).

По данным этой системы в России по состоянию на июнь 2021 г. зарегистрировано 3530 реализуемых проектов ГЧП, из них 8,95\% приходится 
на проекты регионального уровня, общий объем частных инвестиций в которые составляет $32,44 \%$ от общего объема чистых частных инвестиций в такие проекты в общероссийском измерении. Весьма незначительно число проектов федерального уровня - лишь $0,06 \%$ от общероссийского количества проектов (или $0,32 \%$ частных инвестиций), и самое большое число проектов приходится на муниципальный уровень - 90,99\%, но при этом объем частных инвестиций в проекты муниципального уровня составляет лишь $67,24 \%$.

Особую роль в формировании институциональных условий для развития взаимодействия партнёрства со стороны государства и бизнеса в России сыграло совершенствование нормативной правовой базы. Этот процесс продолжается до сих пор и проходит на двух уровнях правового регулирования - федеральном и региональном.

Федеральньй уровень.

Правовое регулирование на федеральном уровне формирует единую терминологию в данной сфере, определяет полномочия сторон при реализации соглашений о государственно-частном партнерстве.

С 1 января 2016 года вступил в силу Федеральный закон от 13.07.2015 № 224-Ф3 «О государственно-частном партнерстве, муниципально-частном партнерстве в Российской Федерации и внесении изменений в отдельные законодательные акты Российской Федерации» (далее - 224-Ф3). Закон определяет основы правового регулирования отношений, возникающих в связи с подготовкой проектов государственно-частного партнерства, заключением, исполнением, прекращением соглашений, в том числе соответствующие полномочия органов власти или самоуправления, устанавливает гарантии прав и интересов участников проектов. Кроме того, 224-Ф3 направлен, в частности, на снятие ограничений и расширение возможных форм реализации проектов на принципах государственно-частного партнерства.

Основные положения 224-Ф3 предполагают, что порядок заключения соглашений о государственно-частном партнерстве должен носить исключительно конкурсный характер. Все данные о проектах должны быть размещены в открытом доступе на официальных сайтах представляющих государственный сектор участников и на официальном сайте, где проводятся торги. В статье 7 Закона определены объекты соглашений, к числу которых относятся различные категории объектов преимущественно социальной инфраструктуры. 
Второй важный закон, регулирующий правоотношения в рамках партнерства между государством и частным сектором, - это федеральный закон от 21.07.2005 № 115-Ф3 «О концессионных соглашениях» (далее - 115-Ф3). Появление этого закона дополнило образование Инвестиционного фонда Российской Федерации и реформирование законодательных основ регионального уровня. Были также запущены механизмы инвестиционной поддержки с государственными гарантиями вложенных средств.

Концессии до 2016 года нельзя было отнести к часто используемой форме государственно-частного партнерства, однако в последние пять лет стали наиболее широко распространенной формой: на муниципальном уровне их доля составляет $84 \%$ от количества всех инфраструктурных проектов, на региональном - 40\%, на федеральном - 60\%. Такое широкое распространение именно концессионных соглашений связано с их долгосрочным характером (25-49 лет), что дает возможность придать стратегический характер партнерству. Кроме того, в концессионных соглашениях у частного сектора есть относительно большая свобода в принятии управленческих и экономических решений.

В 2013 году появился федеральный закон № 44-Ф3 «О контрактной системе в сфере закупок товаров, работ, услуг для обеспечения государственных и муниципальных нужд» (далее - 44-Ф3), который еще больше расширил перечень возможных для реализации форм государственночастного партнерства на практике. Так, например, благодаря этому закону в отечественной практике появилось понятие контракта жизненного цикла.

Согласно условиям такого контракта частный партнер - исполнитель инфраструктурного проекта - за свой счет и с использованием собственных материалов возводит объект и эксплуатирует его в течение всего расчетного срока жизненного цикла, осуществляя ремонт, уход и техническое обслуживание, в то время как публичный партнер оплачивает за счет бюджета соответствующего уровня услуги по предоставлению объекта в общественное пользование (например, предоставление в общее пользование бесплатных автодорог), либо публичные услуги, оказываемые с помощью такого объекта (обучение в школе, вузе; лечение в медицинском учреждении).

Уровень субъектов Российской Федерации.

После принятия в 2016 году федерального закона № 224-Ф3 региональные законы и муниципальные нормативно-правовые акты о партнерстве государства и бизнеса должны быть пересмотрены и приведены в 


\section{ВСЕРОССИЙСКИЕ НАУЧНЫЕ ЧТЕНИЯ

соответствие с основными положениями 224-Ф3 до 1 января 2025 года. А до указанной даты региональные и муниципальные правовые акты могут применяться в той части, в которой они не противоречат нормам федерального законодательства. Ряд регионов уже предприняли попытку доработать свою нормативную базу. Но тем не менее, для регионального законодательства попрежнему присущ целый ряд недостатков:

- отсутствие нормативно закрепленных возможностей для реализации инфраструктурных проектов в соответствии со значительным разнообразием моделей взаимодействия государства и бизнеса, которые распространены в мировой практике;

- наличие рисков противоречия с федеральным законодательством;

- формируемая региональная нормативная база зачастую не учитывает опыт практической реализации проектов государственно-частного партнерства в других регионах, а также те сложности, которые возникают у других регионов в использовании имеющейся нормативной базы.

Важным элементом институциональной среды государственно-частного партнерства в России являются институты его развития, к числу которых относятся государственные институты развития, различные инвестиционные фонды, крупные российские банки, технологические платформы, технопарки и Т.П.

В 2005 года Правительством РФ был учрежден Инвестиционный фонд, основная задача которого заключалась в формировании источников финансирования государственно-частного партнерства. Также по замыслу правительства, он должен был стать катализатором в привлечении частных инвестиций.

Для получения поддержки из Инвестиционного фонда проект должен быть направлен на решение какой-либо важной общественной проблемы, решение которой государство считает приоритетным на текущий момент, также проект должен характеризоваться отрицательной чистой приведенной стоимостью (NPV).

При этом процедура согласования заявки в этом фонде, основываясь на совместной оценке инвестиционных экспертов из государственных министерств и ведомств, а также из привлеченных консультантов частного сектора, была весьма сложной с административной точки зрения. В 2017 году Инвестиционный фонд был упразднен, что было связано с его очевидной 


\section{ВСЕРОССИЙСКИЕ НАУЧНЫЕ ЧТЕНИЯ

неэффективностью в развитии именно механизмов государственно-частного партнерства.

Создание Инвестиционного фонда РФ как основного источника распределения государственных инвестиций при реализации проектов государственно-частного партнерства, привело к появлению институциональных ловушек в его функционировании, а именно к появлению устойчивых неэффективных норм, связанных с согласованием таких проектов, отсутствием прозрачности бюрократических процедур, четких и ясных механизмов контроля за выполнением обязательств по контракту частным партнером при значительных затратах со стороны государственного сектора. Функционирование Инвестиционного фонда РФ также вызывало сомнения у экспертов в целесообразности государственного финансирования целого ряда реализуемых при его участии проектов [3, с. 35-38].

С 2007 года в соответствии с Федеральным законом от 17 мая 2007 г. № 82-Ф3 «О банке развития» был учреждён «Банк развития и внешнеэкономической деятельности (Внешэкономбанк)» (ВЭБ.РФ), считающийся исторически одним из ключевых институтов развития партнерства государства и бизнеса в нашей стране [2, стр. 211-217]. Он представляет собой государственную корпорацию, то есть банковское учреждение, полностью принадлежащее российскому государству (на основе владения 100\% акций). Основная задача «Внешэкономбанка»- стимулирование инвестиционной активности, содействие и поддержка развития инфраструктуры в стране в целом, а также участие в финансировании или иной поддержке проектов, основанных на партнёрстве между государственным и частным секторами.

«Внешэкономбанк» рассматривается как один из институтов, который играет ключевую роль в развитии государственно-частного партнерства на всех его этапах в России, и ответственен в том числе за изучение, стандартизацию и продвижение практики государственно-частного партнерства в России. «Внешэкономбанк», по мнению многих исследователей, является одним из крупнейших в России национальным институтом развития [4, стр. 4-17].

C 2009 года в России функционирует Национальный Центр государственно-частного партнерства, который осуществляет системную деятельность по формирования условий для реализации инфраструктурных проектов на основе государственно-частного партнерства. 
С 2019 года Национальный Центр государственно-частного партнерства в России ввел в действие цифровую платформу «Росинфра», которая в настоящее время выполняет функцию содействия в подготовке и поддержки реализации инфраструктурных проектов, реализация которых базируется на партнерстве государственного и частного секторов.

Каждый субъект Российской Федерации, может разместить свои инвестиционные предложения для поиска частного партнера, а также получить экспертную оценку своих предложений. Появление «Росинфра» явилось важным этапом цифровизации отдельных элементов институциональной среды государственно-частного партнерства в России. Платформа включает в себя следующие ключевые сервисы:

- «База проектов» включается в себя всю основную информацию о проектах (его участники, описание, финансовая структура проекта, объекты, правовая структура проекта);

- «Инвестиционные предложения» содержит данные о проектах государственно-частного партнерства, которые находятся на этапе планирования, здесь также приводится описание потенциальных объектов для проектов, перечень различных инвестиционных площадок и ссылки на официальные страницы партнеров от государственного сектора;

- «Аналитический центр» аккумулирует ссылки на все актуальные публикации в сфере государственно-частного партнерства, а также содержит исследовательскую информацию о финансировании инфраструктурных проектов в России и в других странах мира, данные российских национальных проектов, базу решений Федеральной антимонопольной службы и судебных органов с оценками эффектов, которые эти решения оказали в итоге на рынок.

Несмотря на то, что в целом можно констатировать наличие сформированной и относительно эффективной институциональной среды государственно-частного партнерства в России, ей тем не менее присущи недостатки. В частности, с институциональной точки зрения к их числу относятся низкий уровень прозрачности законодательной базы и недостаточная эффективность организации закупочных процессов для привлечения к торгам высококвалифицированных частных инвесторов с качественно подготовленной документацией по проекту. Еще одним важным институциональным ограничением является ограничение возможностей концессионера предоставить обеспечение в отношении активов, на которые направлен проект, 


\section{ВСЕРОССИЙСКИЕ НАУЧНЫЕ ЧТЕНИЯ

или прав по концессионному соглашению. В соответствии с Федеральным законом о концессиях сторонам не разрешается передавать в залог актив (статья 3 , пункт 6) или права по концессионному соглашению (статья 5, пункт 2), при этом уступка обеспечения таких прав определена периодом после завершения строительства актива.

Хотя в России доступны альтернативные инструменты обеспечения безопасности проекта, такие как залог акций концессионера, ограничения по договору и ценным бумагам, связанным с активами, затрудняют поиск кредиторов и структурирование пакета ценных бумаг. Следует отметить, что ряд региональных законов преодолевают это ограничение. Но сформировавшиеся региональные условия институциональной среды в некоторых случаях не дают возможности привести в соответствие параметры реализации проектов государственно-частного партнерства с требованиями долгосрочных государственных программ развития на региональном уровне.

Подобные институциональные ограничения сокращают диапазон применяемых моделей государственно-частного партнерства, которые могут использоваться для реализации проекта, и ограничивают гибкость для потенциальных инвесторов.

\section{Список литературы}

1) Гайдар Е.Т. Долгое время. Россия в мире: очерки экономической истории. - М.: Дело, 2005.

2) Манько Н.Н. Роль институтов развития в реализации проектов государственно-частного партнерства // Вопросы экономики и права. - 2012. № 45. - С. 211-217.

3) Митрофанова И.В., Сизов Ю.И. Институциональные ловушки инвестиционного фонда РФ // Финансы и кредит. - 2009. - № 3(339). - С. 35-38.

4) Пилипенко И.В. Модель банка развития для содействия активизации инвестиционной деятельности в российской экономике // Экономика и управление: проблемы, решения. - 2020. - Т. 3. - № 2. - С. 4-27.

5) О государственно-частном партнерстве, муниципально-частном партнерстве в Российской Федерации и внесении изменений в отдельные законодательные акты Российской Федерации: Федеральный закон от 13.07.2015 № 224-Ф3: [принят Государственной думой 01 июля 2015 года]: (с 
изменениями и дополнениями). - Доступ из справ.- правовой системы Гарант. Текст: электронный.

6) О контрактной системе в сфере закупок товаров, работ, услуг для обеспечения государственных и муниципальных нужд: Федеральный закон от 5 апреля 2013 г. N 44-Ф3 [принят Государственной думой 22 марта 2013 года]: (с изменениями и дополнениями). - Доступ из справ.-правовой системы Гарант. Текст: электронный.

7) Об инвестиционном фонде Российской Федерации: Постановление Правительства от 23 ноября 2005 года N 694: [утратило силу на основании постановления Правительства Российской Федерации от 1 марта 2008 года N 134] (с изменениями на 31 октября 2007 года). - Доступ из справ.правовой системы Гарант. - Текст: электронный.

8) О государственной корпорации развития «ВЭБ.РФ»: Федеральный закон от 17.05.2007 № 82-Ф3: [принят Государственной думой 20 апреля 2007 года]: (с изменениями и дополнениями).-Доступ из справ.- правовой системы Гарант. -о Текст: электронный.

9) О концессионных соглашениях: Федеральный закон от 21.07.2005 № 115-Ф3: [принят Государственной думой 06 июля 2005 года]: (с изменениями и дополнениями).-Доступ из справ.-правовой системы Гарант. - Текст: электронный. 